비지박 및 맥주박을 이용한 알코올 발효사료의 반추위내 발효특성 및 건물 분해율에 미치는 영향

신종서 $\square$ 임광철* $\square$ 김병완

\title{
The Effect of Alcohol Fermented Feedstuff Made of Byproducts on Fermentation Characteristics and Dry Matter Disappearance in the Rumen
}

\author{
Jong Suh Shin, Guang Zhe Lin* and Byong Wan Kim
}

\begin{abstract}
A study was conducted to determine the effect of alcohol-fermented feedstuff formulated with byproducts on the fermentation characteristics and dry matter disappearance in the rumen. Dietary treatments were either a soybean curd-based alcohol-fermented feedstuff (AFS) and brewery grain-based alcohol-fermented feedstuff (AFB). The AFS and AFB are composed of 50\% commercial beef cattle feed, $50 \%$ soybean curd dreg, $5 \%$ molasses and $0.5 \%$ yeast, and $25 \%$ commercial beef cattle feed, $25 \%$ brewery grain, $25 \%$ soybean curd dreg, $25 \%$ corn grit, $5 \%$ molasses and $0.5 \%$ yeast, respectively. The ruminally cannualted Korean cattle were utilized to investigate the change of ammonia, $\mathrm{pH}$ alcohol, volatile fatty acids, and DM digestibility at $0,2,4,8$ and $12 \mathrm{hr}$ after feeding. The rumen ammonia concentrations were significantly lower in AFS and AFB with incubation time, especially at $6 \mathrm{hr}$ incubation (AFS, $0.7 \mathrm{mg} / \mathrm{dl}$; AFB, 1.5 $\mathrm{mg} / \mathrm{dl}$; control $2.5 \mathrm{mg} / \mathrm{dl}$ ). Lower rumen $\mathrm{pH}$ was observed in AFS and AFB during the early stage of incubation, but no significant difference was found at late stage of incubation. The total VFA concentrations were not affected by diet treatments at $2 \mathrm{hr}$ incubation time, but the concentration significantly decreased after that. The dry matter disappearance was significantly lower in AFS and AFB during the early stage of incubation. However, the dry matter disappearance of AFS and AFB was similar to that of control during the late stage of incubation. It is concluded that the industrial byproducts such as soybean curd dreg and brewery grain were effective materials to make an alcohol fermented feedstuffs and resulted in better fermentation characteristics in the rumen when both were applied to Hanwoo.
\end{abstract}

(Key words : Alcohol-fermented feedstuff, pH, Ammonia, Alcohol, VFA’s, Dry matter disappearance)

$\begin{array}{cl}\text { I . 서 론 } & \text { 하고자 하는 관심이 고조되고 있으며, 특히 비 } \\ & \text { 지박 및 맥주박을 반추가축의 사료자원으로 널 } \\ \text { 최근 옥수수 등의 곡물가격이 폭등함에 따라 } & \text { 리 이용되고 있다. 그러나 두부와 맥주를 생산 } \\ \text { 산업적으로 생산되는 부산물들을 가축에 이용 } & \text { 하고 난 산업 부산물인 비지박과 맥주박은 단 }\end{array}$

강원대학교 동물생명과학대학 (College of Animal Life Science, Kangwon National University, Korea)

* College of Life Science, Linyi Normal University. Linyi, Shandong, China

Corresponding author: Byong Wan Kim, College of Animal Life Sciences, Kangwon National University, Chuncheon 200-701, Korea.

Tel: +82-33-250-8628, Fax: +82-33-250-2532, E-mail: bwkim@kangwon.ac.kr 
백질 함량이 대략 건물기준으로 $24 \%$ 정도이며, 리그린 함량은 거의 없는 사료적 가치가 매우 높은 자원이다. 그러나 수분 함량이 높아 실온 에서 부패로 인하여 저장성이 매우 떨어져 별 도의 처리없이 반추가축에 급여하면 기호성이 저하되는 단점을 지니고 있다. 이러한 문제점 을 해결하고자 젖산균을 이용한 발효처리, 건 조처리(Armentano 등, 1986) 등에 의한 사료화 방안이 제시되고 있으나, 그 효과가 미흡한 실 정에 있어 비지박 및 맥주박 등의 산업 부산물 의 사료화 방안에 대한 연구가 절실한 시점에 있다.

반추위내 알코올 처리는 반추미생물의 TVFA 생성량을 증가시키는 한편, acetyl-CoA 생성과 정을 촉진시켜 acetate, butyrate, valerate 및 caproate 생성비율을 증가시키고 이들 간에 일 정한 균형을 유지시켜준다. 또한 알코올 발효 사료처리는 알코올 뿐만 아니라 젖산을 함유하 고 있으므로 반추위내 발효과정을 전체적으로 억제하여 TVFA 생성량을 저하시키는 동시에 propionate 생성비율과 ammonia 생성량을 억제 하는 것으로 밝혀졌다(신과 박, 2006; 신 등, 2005; 임 등, 2001, 임 등, 1999). 알코올은 반 추위내 이용효율은 저조하지만 대부분 반추위 벽을 통해 흡수되어 에너지원으로 이용된다. 반면에 알코올 발효사료처리는 반추위내 ammonia, $\mathrm{pH}$, lactate, alcohol 및 dextrose 생성량을 변화 시키는 것으로 보고하고 있다(임 등, 2001; 신 등, 2005) 이와 같이 알코올과 알코올 발효사료 는 반추위내 발효 pattern에 미치는 영향이 상 당한 차이점을 가지고 있다.

이러한 관점에서 산업적으로 다량 생산되고 비지박 및 맥주박을 이용한 알코올 발효사료를 제조하여 반추가축의 생산성을 높이기 위한 방 안이 모색되어야 한다. 특히 수분이 높은 부산 물들은 미생물을 이용하여 발효처리하면 저장 성 뿐 만 아니라 기호성등이 개선되며, 발효과 정에서 생성되는 알코올 등의 발효산물 등에 의해 사료적 가치가 향상되는 것으로 알려져
있다. 그러나 비지박 및 맥주박은 별도의 처리 없이 반추가축의 사료자원으로 활용되고 있는 실정이며, 아직까지 미생물을 이용하여 사료적 가치를 높이려는 연구가 미흡하며, 반추위내 발효 pattern의 변화에 대한 평가가 확실히 밝 혀진바 없다.

따라서 본 실험은 미생물을 이용하여 제조한 비지박 및 맥주박의 알코올 발효사료 처리가 반추위내 $\mathrm{pH}$, 암모니아, 알코올 및 휘발성지방 산 농도와 건물 분해율에 미치는 영향을 검토 하고자 실시하였다.

\section{II. 재료 및 방법}

\section{1. 시험장소 및 공시동물}

본 실험은 강원대학교 부속실험목장에서 반 추위에 cannula를 장착한 한우 $(500 \mathrm{~kg})$ 2두를 이용하여 3 개월간 실시하였다.

\section{2. 시험사료 제조}

비지박 알코올 발효사료는 비지박(DM 20\%) 과 분말배합사료(DM 87\%)를 $50: 50$ 의 비율로 혼합하고 당밀 $2 \%$, yeast $0.5 \%$ 를 첨가한 후 30 ${ }^{\circ} \mathrm{C}$ 에서 72 시간 혐기적으로 배양하여 제조하였 으며, 맥주박 알코올 발효사료는 맥주박(DM $25 \%)$, 비지박(DM 20\%), 옥분 및 분말배합사료 를 $25: 25: 25: 25$ 의 비율로 혼합하고 당밀 $5 \%$, yeast $0.5 \%$ 를 첨가한 후 $30^{\circ} \mathrm{C}$ 에서 24 시간 혐기 적으로 배양하여 제조하였다.

\section{3. 시험사료의 화학 조성분 분석}

본 시험에 이용된 시험사료의 일반 화학성분 은 AOAC (1990) 방법에 준하여 분석하였다. 또 한 시험사료의 $\mathrm{pH}$ 및 alcohol 농도를 측정하기 위해 각 시험사료를 $1 \mathrm{~g}$ 을 3 차 증류수를 이용하 여 5 배 희석하여 vortex mixer로 15 분간 혼합한 
후 $4^{\circ} \mathrm{C}$ 에서 30 분간 정치하고, $3,000 \mathrm{rpm}$ 에서 5 분간 원심분리하여 상층액을 분리한 후 $\mathrm{pH}$ 및 alcohol 농도를 측정하였다. $\mathrm{pH}$ 는 $\mathrm{pH}$ meter (Corning 445, USA)를 이용하여 측정하였으며, alcohol 농도는 glucose analyzer(YSI 2700, USA)를 이용하여 조사하였다. 시험사료의 화학 성분은 Table 1 과 같다.

\section{4. 시험설계}

(1) 알코올 발효사료의 반추위내 발효 특성 대조구는 시판 비육우 배합사료 $70.5 \%$ 와 Sudan grass silage $29.5 \%$ 를 체중의 $1.7 \%(\mathrm{DM})$ 되 도록 급여하였으며, 처리구는 비육우 배합사료 $45 \%$, 비지박 및 맥주박 알코올 발효사료를 각 각 $26.5 \%$, sudan grass silage $28.5 \%$ 를 대조구와 동등한 건물량으로 급여하였다 (Table 2). 처리 구는 7일간의 예비 시험기간을 두었으며, 예비 시험기간 동안 시험구와 동일한 사료를 급여하 였다. 대조구 및 시험구는 시험사료급여 후 0 , 2, 4, 6, 8 및 12시간별로 반추위 캐눌라를 통 해 반추위액을 채취하였으며, 채취한 반추위액 은 4겹의 cheese cloth로 거른 후 즉시 $\mathrm{pH}$ 를 측 정하고 두 개의 $15 \mathrm{ml}$ 원심분리 tube에 각각 5 $\mathrm{m} \ell$ 씩 담아 분석시까지 $-20^{\circ} \mathrm{C}$ 에서 냉동 보관 하였다. 이중 한 개는 ammonia 함량 및 알코올 함량 측정에 직접 이용하였으며, 나머지 한 개 는 휘발성 지방산 분석용으로 사용하기 위하여 $25 \%$ 의 $\mathrm{HPO}_{3} 1 \mathrm{ml}$ 와 $0.5 \mathrm{ml}$ 의 포화 $\mathrm{HgCl}_{2}$ 를 첨 가한 후 냉동 보관한 후 분석에 이용하였다. 반추위내 In situ 배양 $0,2,4,6,8$ 및 12 시간 별로 각각 배양액을 채취하는 즉시 $\mathrm{pH}$ meter (Corning 445, USA)로 $\mathrm{pH}$ 를 측정하고, 3,000 $\operatorname{rpm}\left(0^{\circ} \mathrm{C}\right)$ 에서 5 분간 원심 분리한 후 상층액을 취하여 alcohol 및 ammonia 농도 측정에 이용 하였다. Alcohol 농도는 glucose analyzer(YSI 2700 , USA)를 이용하여 분석하였으며, ammonia 농도는 자동분석기 (Quikchem 8000, USA)를 이 용하여 측정하였다.

\section{(2) In situ 건물 분해율}

시험시료의 가용성 건물 $S$ (truly soluble fraction)는 Dhanoa 등(1999)의 방법에 따라 500 $\mathrm{ml}$ 삼각 플라스크에 $1 \mathrm{~g}$ 의 시험시료를 담고 50 $\mathrm{ml}$ 의 증류수를 넣은 후 $39^{\circ} \mathrm{C}$ 에서 1 시간동안 흔들어 가용성물질을 용해시켰다. 용해가 완료 된 시료는 Whatman No 1 filter paper를 이용하 여 불용성 부분을 걸러내고 $70^{\circ} \mathrm{C}$ dry oven에서

Table 1. Chemical composition of experimental diets

\begin{tabular}{lcccc}
\hline Item & Commercial feed & Sudan grass silage & AFS $^{\mathrm{a}}$ & AFB $^{\mathrm{b}}$ \\
\hline \hline Dry matter, \% & $87.8 \pm 0.1$ & $22.2 \pm 4.0$ & $52.4 \pm 0.9$ & $50.8 \pm 1.4$ \\
& $\ldots \ldots \ldots \ldots \ldots \ldots \ldots \ldots \ldots \ldots \ldots \ldots \ldots \ldots \ldots \ldots \ldots \ldots$ \\
Crude protein, \% & $15.3 \pm 0.2$ & $9.9 \pm 0.6$ & $15.5 \pm 0.1$ & $14.9 \pm 0.4$ \\
Ether extracts, \% & $4.2 \pm 0.1$ & $3.0 \pm 0.7$ & $3.7 \pm 0.2$ & $3.3 \pm 0.3$ \\
Crude fiber, \% & $3.0 \pm 0.2$ & $33.1 \pm 1.0$ & $10.0 \pm 0.4$ & $10.2 \pm 0.3$ \\
Ash, \% & $7.7 \pm 0.1$ & $6.8 \pm 2.9$ & $6.8 \pm 0.2$ & $4.9 \pm 0.4$ \\
Alcohol, \% & - & $0.9 \pm 0.1$ & $3.0 \pm 0.2$ & $3.1 \pm 0.1$ \\
Lactate, \% & - & $4.5 \pm 0.4$ & $3.1 \pm 0.4$ & $3.3 \pm 0.5$ \\
Ammonia, mg/100g & - & - & $69.1 \pm 4.5$ & $200.2 \pm 6.0$ \\
pH & - & $3.8 \pm 0.1$ & 4.5 & 4.5 \\
\hline
\end{tabular}

\footnotetext{
alcohol-fermented soy bean curd dregs.

b Alcohol-fermented brewery grain's.

- Not detected.
} 
Table 2. Chemical composition of experimental diets for in situ trials

\begin{tabular}{lccc}
\hline Item & Control & AFS & AFB \\
\hline \hline & $\ldots \ldots \ldots \ldots \ldots \ldots \ldots$ & \% of dry matter $\ldots \ldots \ldots \ldots \ldots \ldots \ldots$ \\
Ingredient & & & \\
Commercial feed stuff, \% & 70.5 & 45.0 & 45.0 \\
AFS , \% & - & 26.5 & - \\
AFB ${ }^{\text {b, \% }}$ & & & 26.5 \\
Sudan grass silage, \% & 29.5 & 28.5 & 28.5 \\
\hline Calculated chemical composition & & & \\
Crude protein, \% & $13.7 \pm 0.3$ & $14.0 \pm 0.5$ & $13.7 \pm 0.3$ \\
Ether extracts, \% & $3.8 \pm 0.2$ & $3.7 \pm 0.3$ & $3.6 \pm 0.4$ \\
Crude fiber, \% & $11.9 \pm 0.9$ & $13.4 \pm 1.0$ & $13.5 \pm 0.7$ \\
Ash, \% & $7.4 \pm 0.5$ & $7.2 \pm 1.1$ & $6.7 \pm 1.0$ \\
Alcohol, \% & $0.3 \pm 0.1$ & $1.0 \pm 0.1$ & $1.1 \pm 0.2$ \\
Lactate, \% & $1.3 \pm 0.5$ & $2.1 \pm 0.2$ & $2.2 \pm 0.3$ \\
\hline
\end{tabular}

a Alcohol-fermented soy bean curd dregs.

b Alcohol-fermented brewery grain's.

72시간 건조시킨 후 무게를 측정하여 가용성물 질의 손실을 측정하였다. 각각의 시험사료를 fiber filter bag (F54)에 $5 \mathrm{~g}(\mathrm{DM})$ 씩 담은 후 반추 위 cannula를 통해 반추위내에 넣고 $0,2,4,6$, 8 및 12시간동안 배양하였다. 반추위내 배양이 완료된 fiber filter bag(F54)은 수돗물로 맑은 물이 나올 때까지 세척한 후 $70^{\circ} \mathrm{C}$ dry oven에 서 72 시간 건조하고 무게를 측정하여 건물 소 실율을 계산하였다. 한편, 시험시료의 시간별 건물소실은 Dhanoa 등(1999)의 방법에 따라 반 추위내 0시간째에 fiber filter bag으로부터 유실 된 부분에서 직접 측정된 가용성 부분 $\mathrm{S}$ 를 공 제하여 불용성 미립자 소실량 $\beta$ (escaped insoluble fraction)로 하고 Dhanoa 등 (1999)의 가설에 따라 $\beta_{\mathrm{D}}$ (분해성 미립자)와 $\beta_{\mathrm{U}}$ (미분해 성 미립자) 비율을 계산한 후 각 시점에서 측 정된 소실율을 보정하였다.

Dhanoa 계산식 :

$\beta=\beta_{D}+\beta_{U}, \quad \beta_{D}=\beta B /(1-A), \quad \beta_{U}=\beta(1-A-B) /$ (1-A);

$$
\begin{aligned}
& \mathrm{P}=(\mathrm{A}-\beta)+\left(\mathrm{B}+\beta_{\mathrm{D}}\right)\left(1-\mathrm{e}^{-\mathrm{cT}}\right)=S+D\left(1-\mathrm{e}^{-\mathrm{cT}}\right) \\
& \mathrm{EP}=(\mathrm{A}-\beta)+\left(\mathrm{B}+\beta_{\mathrm{D}}\right) \mathrm{ce}^{-\mathrm{kpT}} /\left(\mathrm{c}+\mathrm{k}_{\mathrm{p}}\right) .
\end{aligned}
$$

Where;

$\beta$ : Escaped insoluble fraction,

$\beta_{D}$ : Degradable escaped insoluble fraction,

$\beta_{U}$ : Undegradable escaped insoluble fraction,

$\mathrm{P}$ : Disappearance rate.

A : Escaped fraction at 0 time.

B : Degradable part of the insoluble fraction.

$S \quad$ : Truly soluble fraction.

$D$ : Truly degradable part of the insoluble fraction.

$C$ : Fractional degradation rate.

$\mathrm{T}$ : Incubation time in the rumen.

EP : Effective disappearance rate.

$k_{p} \quad$ : Estimated ruminal rate of passage.

\section{5. 통계분석}

본 실험에서 얻은 결과들은 SAS package (1999)를 이용하여 분산분석 및 Duncan의 multiple range test를 실시하여 처리구간의 유의성 
$(\mathrm{p}<0.05)$ 을 검증하였다.

\section{III. 결과 및 고찰}

1. 반추위내 ammonia 농도, $\mathrm{pH}$ 및 알코올 농도 변화

비지박 및 맥주박 알코올 발효사료(AFS 및 $\mathrm{AFB})$ 급여에 따른 반추위내 ammonia 농도, $\mathrm{pH}$ 및 알코올 농도를 조사한 결과는 Fig. 1, 2 및 3에서 나타낸 바와 같다.

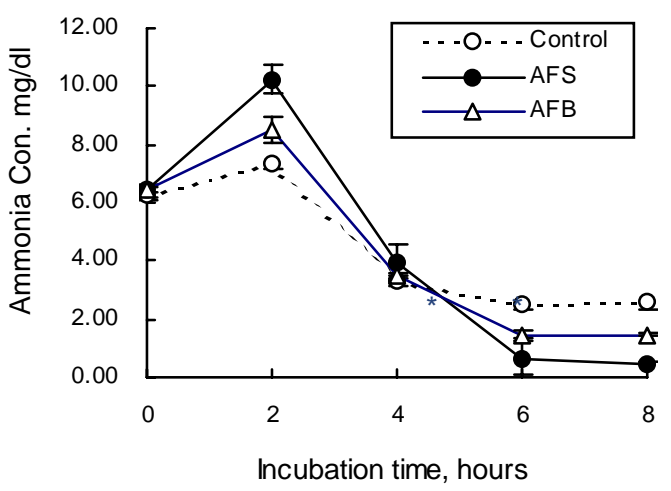

Fig. 1. Ammonia concentrations in the rumen over incubation time of alcoholfermented soybean curd dreg(AFS) and alcohol-fermented brewery grain's (AFB).

반추위액 중 ammonia 농도는 in situ 배양 2 시간에 $\mathrm{AFS}$ 및 $\mathrm{AFB}$ 구가 각각 10.2 및 8.5 $\mathrm{mg} / \mathrm{dl}$ 로 대조구의 $7.4 \mathrm{mg} / \mathrm{dl}$ 에 비해 유의적으로 높게 나타났으나 $(\mathrm{p}<0.05)$ 배양 2시간부터 6시간 사이에 ammonia 농도는 $\mathrm{AFS}$ 및 $\mathrm{AFB}$ 구가 각 각 2.4 및 $1.8 \mathrm{mg} / \mathrm{dl} / \mathrm{h}$ 의 빠른 속도로 감소하고 대조구는 $1.2 \mathrm{mg} / \mathrm{dl} / \mathrm{h}$ 로 대조구에 비해 완만히 감소하였으며, 배양 6시간째 반추위액중의 ammonia 농도는 $\mathrm{AFS}$ 및 $\mathrm{AFB}$ 구가 각각 0.7 및 $1.5 \mathrm{mg} / \mathrm{dl}$ 로 대조구의 $2.5 \mathrm{mg} / \mathrm{dl}$ 보다 낮게 나타 났다 $(\mathrm{p}<0.05)$. 이러한 결과는 엄 등 $(2002)$ 의 옥 수수 알코올 발효사료를 이용하였을 경우, 대

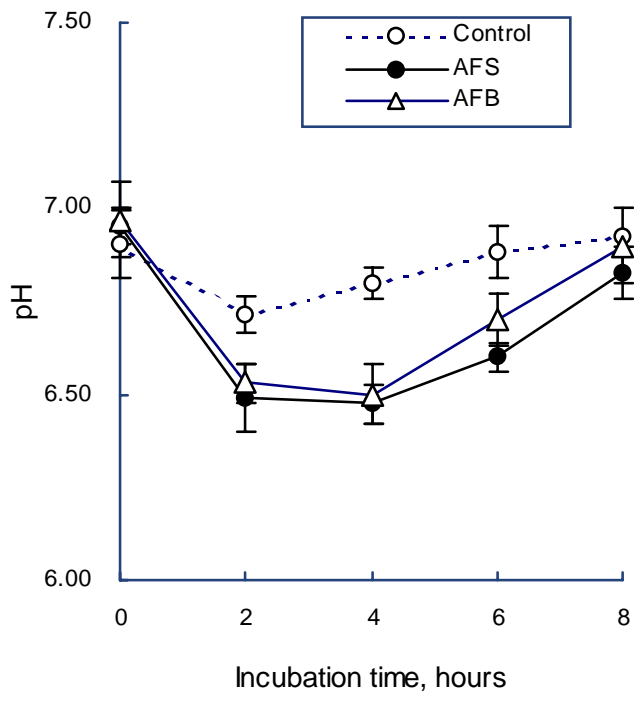

Fig. 2. Rumen $\mathrm{pH}$ over incubation time of alcohol-fermented soybean curd dreg (AFS) and alcohol-fermented brewery grain's (AFB).

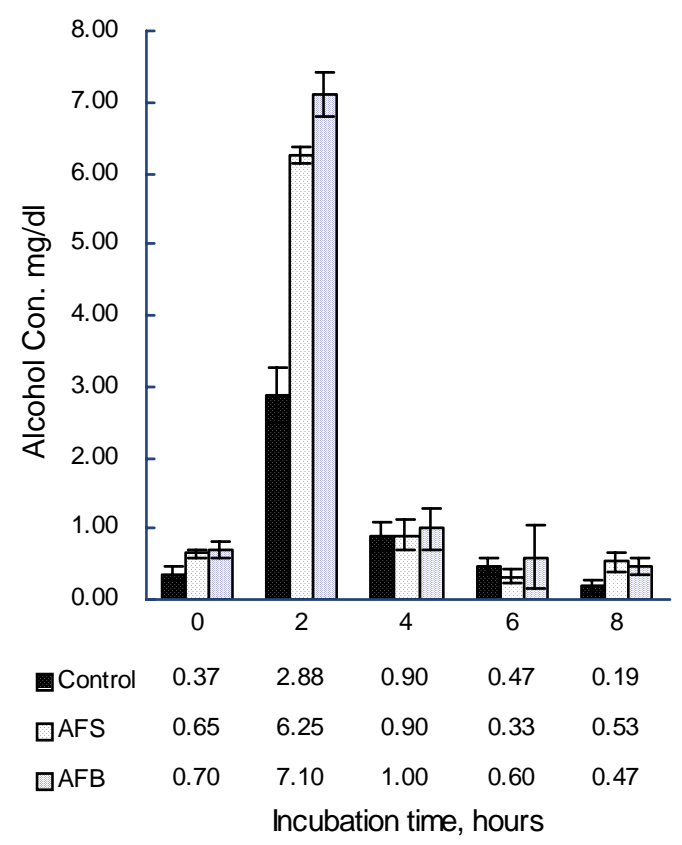

Fig. 3. Alcohol concentrations in the rumen over incubation time of alcoholfermented soybean curd dreg (AFS) and alcohol-fermented brewery grain (AFB). 
조구에 비해 ammonia 함량이 낮았다는 결과와 차이가 있는데 이는 엄 등(2002)이 이용하였던 대조구 사료가 알코올 발효사료보다 단백질 함 량이 $3 \%$ 정도 높았던 반면 본 실험에서는 대 조구 사료가 알코올 발효사료들보다 단백질 함 량이 높지 않았기 때문으로 판단된다. 또한 이 러한 결과는 비지박 및 맥주박 알코올 발효사 료들이 가공과정이나 발효과정에서 미분해단백 질 성분이 증가하기 때문으로 추측되어진다. 한편, 大㭇 등 (1991)은 사료에 $5 \%$ 알코올을 첨가하여 급여하면 반추위내 ammonia 농도를 현저히 감소시킨다고 보고하고 있어 단순히 알 코올을 급여하는 경우와 알코올 발효사료를 급 여하는 경우간의 ammonia 생성량은 현저한 차 이가 있음을 시사한다. 알코올 발효사료의 급 여로 사료급여 초기의 반추위내 ammonia 농도 가 증가되는 원인은 알코올 발효과정에서 ammonia 함량이 증가하며, 사멸된 균체단백질 의 분해(Burning과 Yokoyama, 1988), 알코올 발효과정에서 미생물의 단백질 대사에 의한 대 사 중간산물 (아미노산 등)의 생성 등 반추위내 에서 빨리 분해되는 단백질 함량이 증가되기 때문으로 판단되며, yeast균에 의한 반추위내 proteolytic bacteria수의 증가(Yoon과 Stern, 1996) 및 사료급여 초기단계에 있어서 알코올 발효사 료중의 젖산 및 알코올이 반추 미생물의 증식 에 대한 억제작용으로 (Mackenzie, 1967; 大梘 등, 1991) ammonia 이용속도가 저하되는데도 관련되는 것으로 판단된다. 그러나 반추위내 발효시간이 경과하면서 젖산 및 알코올은 미생 물에 의해 분해 및 이용되거나 흡수되면서 반 추미생물의 증식이 활발해짐에 따라 ammonia 이용속도가 현저히 빨라졌으며, 대부분의 가용 성 단백질은 발효 초기에 소실됨에 따라 발효 후기의 단백질 분해속도가 대조구에 비해 떨어 지는 원인으로 배양 6,8 시간에 알코올 발효사 료 급여구의 ammonia 농도가 대조구에 비해 낮게 나타난 것으로 판단된다.

반추위내 $\mathrm{pH}$ 는 $\mathrm{AFS}$ 및 $\mathrm{AFB}$ 구가 사료급여 2
시간에 6.49 및 6.53으로 대조구의 6.7에 비해 유의적으로 낮게 나타났으며 $(\mathrm{p}<0.05)$, 배양시간 이 경과하면서 서서히 증가하여 사료급여 8시 간에 대조구와 유사한 수준으로 회복되는 것으 로 나타났다. 이러한 결과는 엄 등 (2002)이 옥 수수 알코올 발효사료를 급여하여 측정한 $\mathrm{pH}$ 의 결과와 유사하나 알코올 급여 시에 반추위내 $\mathrm{pH}$ 에 영향을 미치지 않았다는 大柣 등(1991)의 보고와는 상이하였다. 이는 알코올 발효사료가 발효과정에 알코올 뿐만 아니라 다량의 젖산을 생성하고 $\mathrm{pH}$ 가 낮았기 때문에 반추위내 $\mathrm{pH}$ 를 일시적으로 저하시키는 경향을 보였으나 시간이 경과하면서 반추미생물에 의해 젖산이 분해 및 이용되고 반추에 의한 타액의 유입으로 $\mathrm{pH}$ 가 서서히 회복되는 것으로 판단된다.

반추위내 알코올 농도는 사료급여 2시간에 AFS 및 $\mathrm{AFB}$ 구가 각각 6.3 및 $7.0 \mathrm{mg} / \mathrm{dl}$ 로 대조 구의 $2.9 \mathrm{mg} / \mathrm{dl}$ 보다 높은 결과를 보였으나 급 여 4시간에 각각의 처리구들이 대조구와 유사 한 수준인 $0.9 \mathrm{mg} / \mathrm{dl}$ 전후로 감소하는 것으로 나타났다. 반추위액 중의 알코올 농도의 증가 는 주로 시험사료 중의 알코올로부터 유래되 며, 대조구에서도 다소 증가되는 경향을 보인 것은 silage 급여에 따라 silage 중에 존재하던 알코올에서 기인되기 때문인 것으로 판단된다 (Andree 등, 1991; Moloney와 Kiely, 1999). 그 러나 알코올 농도는 사료급여 4시간에 급여전 의 수준으로 급격히 저하되고 더 이상 증가되 지 않는 것은 반추위벽을 통해 신속히 흡수 및 제거되기 때문으로 판단된다. Burning과 Yokoyama (1988)은 반추위 cannulae를 통해 Hereford 비육 우에게 1 차적으로 $160 \mathrm{~g}$ 의 알코올을 투여할 경 우, 투여 3시간 후에 혈중 알코올 농도가 7.1 $\mathrm{mg} / \mathrm{dl}$ 로 급증한다고 보고하였으며, Andree 등 (1991)은 in vitro 실험에서 알코올이 반추미생 물에 의해 휘발성 지방산으로 전환되는 비율이 9 22\%에 불과하다고 보고하고 있어 본 실험 의 결과를 뒷받침해 주고 있다. 또한 사료급여 8시간에 알코올 발효사료 급여구의 알코올 농 
도가 대조구에 비해 유의적으로 높게 나타났는 데 $(\mathrm{p}<0.05)$, 이는 알코올 발효사료 중에 존재하 는 yeast 균에 의해 알코올이 일부 생성되기 때 문으로 판단된다. 또한 알코올 발효사료급여는 반추위내에서 알코올 생성을 가능하게 하여 알 코올의 체내 흡수량을 증가시킬 수 있었기 때 문으로 판단된다.

\section{TVFA 생성량 및 조성비율}

알코올 발효사료 급여에 따른 반추위내 총휘 발성 지방산(total volatile fatty acid: TVFA) 생 성량 및 VFA 조성비율을 조사한 결과는 Fig. 4, 5, 6 및 7에서 나타내고 있다.

반추위내 TVFA 생성량은 사료급여 2시간에 가장 높은 수준을 보였으며, 이때 AFS구는 $79.1 \mathrm{mM} / \mathrm{l}$ 로 대조구의 $77.8 \mathrm{mM} / \mathrm{l}$ 에 비해 유의성 은 없었으나 증가하는 경향을 보였으며, $\mathrm{AFB}$
구는 대조구에 비해 현저히 감소하는 결과로 나타났다. 배양 4시간부터 8시간 사이에는 알 코올 발효사료구의 TVFA 생성량은 대조구보 다 낮은 수준으로 나타났다 $(\mathrm{p}<0.05)$.

Acetate 비율은 배양 2시간에 알코올 발효사 료구들이 대조구보다 낮게 나타난 반면에 $(\mathrm{p}<$ 0.05) 배양 6시간에 알코올 발효사료 급여구들 이 대조구보다 높게 나타났다 $(\mathrm{p}<0.05)$. 또한 propionate 비율은 배양 2시간에 AFS 및 $\mathrm{AFB}$ 구가 21.8 및 $22.0 \mathrm{M} \%$ 로 대조구의 $18.6 \mathrm{M} \%$ 에 비해 높게 나타났으나 $(\mathrm{p}<0.05)$ 배양 8 시간에 대 조구와 $\mathrm{AFS}$ 및 $\mathrm{AFB}$ 구간에 유사한 수준으로 나타났다. 이는 엄 등(2002)이 옥수수 알코올 발효사료를 이용하여 반추위내 propionat 생성 비율을 조사한 결과와 유사하나 알코올 첨가효 과(大㭇 등, 1991; 이, 1999)와는 상반된다.

아미노산(valine)의 분해 대사와 밀접한 관계 가 있는 isobutyrate는 배양 4시간까지 처리간에

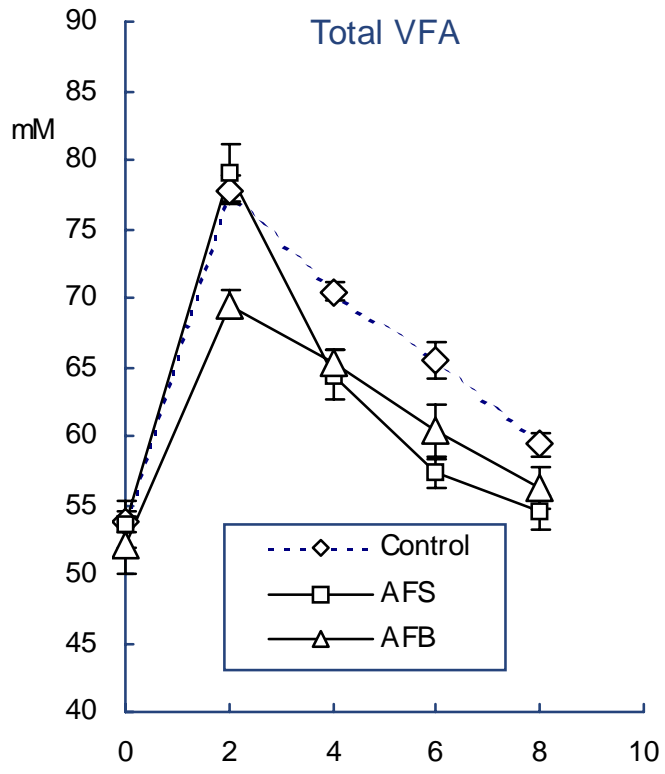

Incubation time, hours

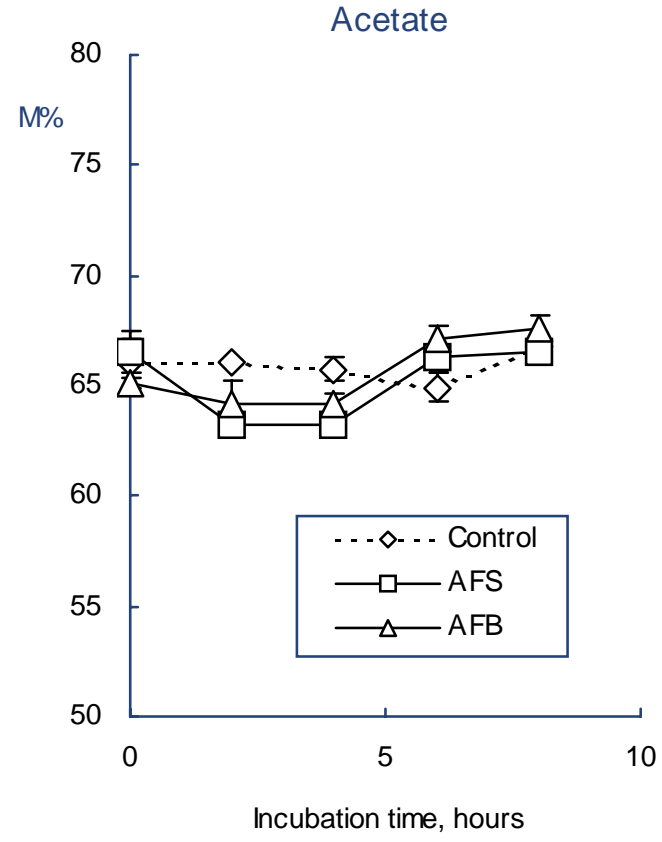

Fig. 4. Molar concentrations of total volatile fatty acids and molar percentage of acetate over incubation time of alcohol-fermented soybean curd dreg (AFS) and alcoholfermented brewery grain (AFB). 

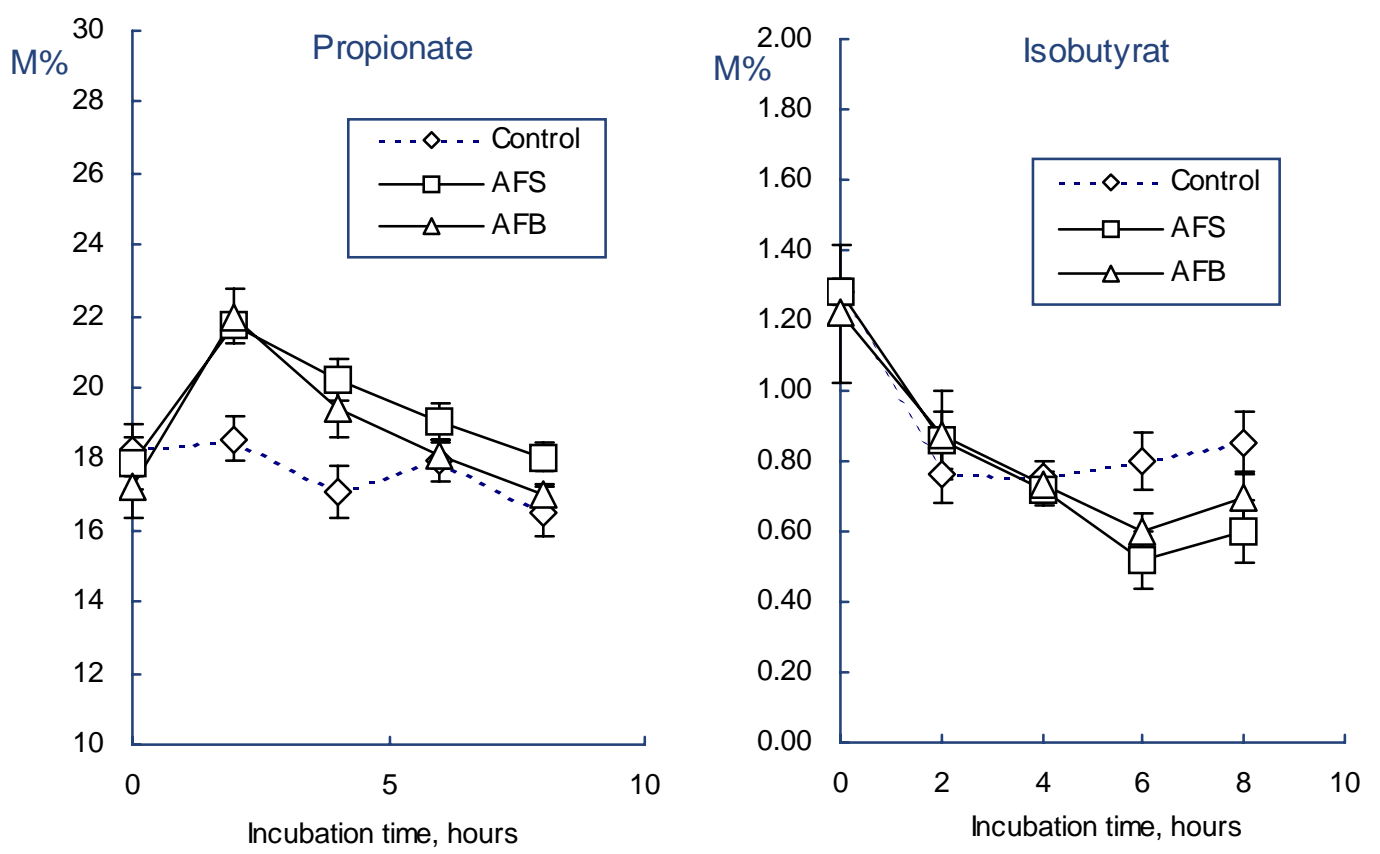

Fig. 5. Molar percentage of propionate and isobutyrate over incubation time of alcoholfermented soybean curd dreg (AFS) and alcohol-fermented brewery grain (AFB).
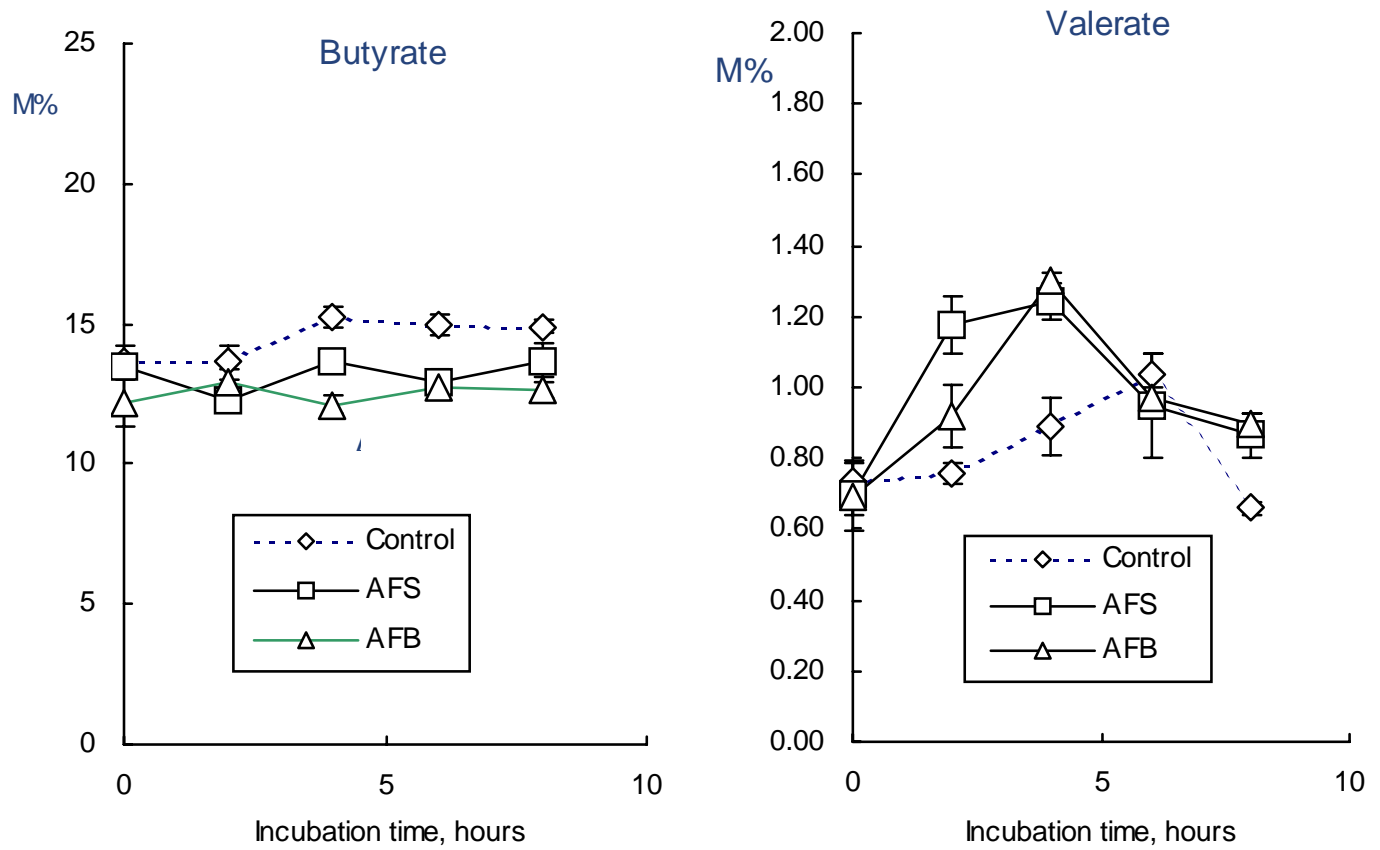

Fig. 6. Molar percentage of butyrate and valerate over incubation time of alcohol-fermented soybean curd dreg (AFS) and alcohol-fermented brewery grain (AFB). 


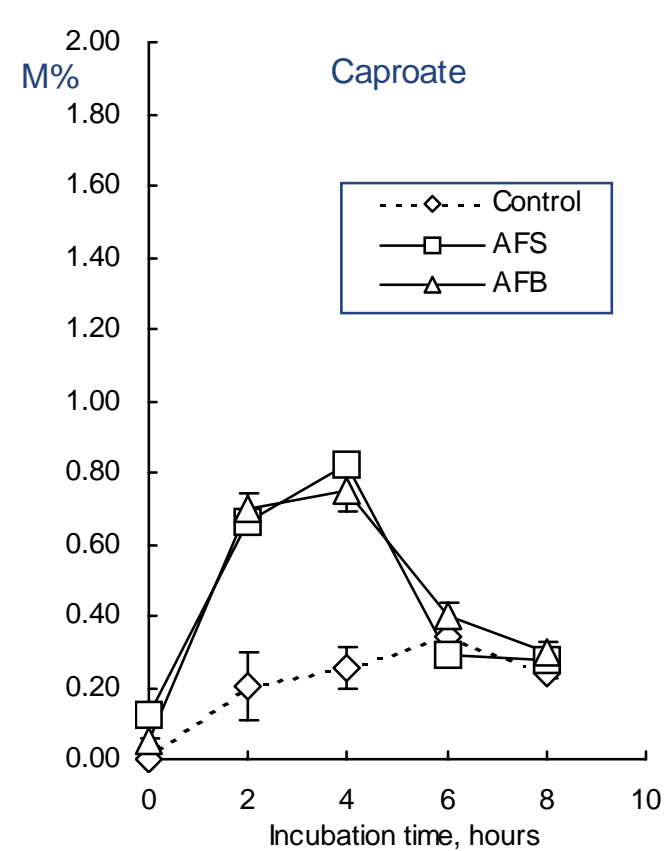

Fig. 7. Molar percentage of caproate over incubation time of alcohol-fermented soybean curd dreg (AFS) and alcoholfermented brewery grain (AFB).

유사한 수준을 나타났다. 배양 6시간에 AFS 및 $\mathrm{AFB}$ 구가 각각 0.52 및 $0.60 \mathrm{M} \%$ 로 대조구의 $0.8 \mathrm{M} \%$ 에 비해 유의적으로 감소하는 것으로 나타났다 $(\mathrm{p}<0.05)$. Butyrate 비율은 처리구들이 전 시험기간 동안 대조구보다 낮은 수준을 유 지하였으며 $(\mathrm{p}<0.05)$, 배양시간에 따른 butyrate 비율은 변화없이 일정하게 유지하는 것으로 나 타났다. 그리고 valerate 및 caproate 비율은 배 양 2시간부터 4시간 사이에 알코올 발효사료 급여구들이 대조구보다 높은 결과로 나타났으 나 $(\mathrm{p}<0.05)$ 배양 6 시간 이후로부터는 대조구와 유사한 수준으로 나타났다.

이상의 시험결과에서 알코올 발효사료 급여 는 사료급여 초기의 반추위내 ammonia 농도를 증가시키고 $\mathrm{pH}$ 를 저하시키나 시간이 경과하면 서 사료급여 전의 수준을 회복되는 것으로 나 타났는데, 이는 알코올 발효사료 중의 ammonia 및 낮은 $\mathrm{pH}$ 의 영향에 의한 것으로 판단된다.
또한 알코올 발효사료 급여로 반추위내 TVAF 생성량이 감소되는 경향을 보였으며, propionate 및 valerate 생성비율이 증가되는 양상을 보인 것은 알코올 발효사료 중에 존재하는 lactate와 밀접한 관계가 있는 것으로 판단된다. 일반적 으로 lactate의 반추위벽을 통한 흡수속도는 휘 발성 지방산의 $1 / 8$ 정도로(Williams와 Mackenzie, 1965) 기타 휘발성 지방산이 반추위벽을 통해 신속히 흡수되는 동안 lactate는 반추위내에서 반추미생물에 의해 propionate로 전환되므로 propionate 생성비율이 상대적으로 증가하게 된 다. 일반적으로 반추미생물에 의한 탄수화물의 발효는 산화환원반응이 평형을 이루는 과정으 로 $\mathrm{pH}$ 가 낮을 경우(산화도가 높음) 환원성 물 질의 생성을 증가시키게 된다. 따라서 glucose 로부터 propionate 및 valerate(환원성 물질) 생 성과정이 촉진되는 반면에 acetate 및 butyrate (산화성 물질) 생성과정이 억제되게 되므로 낮 은 $\mathrm{pH}$ 조건에서 acetate 및 butyrate 비율이 현 저히 감소하는 것으로 판단된다. 그러나 본 실 험에서 propionate 비율은 사료급여 초기(2시간) 에 급격히 증가하였다가 그 이후로는 급격히 감소하는 동시에 이 시점에서 TVFA 생성량이 대조구와 유사한 수준을 나타낸 것으로부터 알 코올 발효사료 급여에 따라 유입된 젖산은 반 추미생물에 의해 신속히 propionate로 전환되었 기 때문으로 사료된다.

한편, isobutyrate 비율과 ammonia 농도가 배 양시간이 경과하면서 동시에 대조구에 비해 감 소하는 것은 알코올 발효사료의 단백질 분해율 이 낮기 때문으로 판단된다. 또한 알코올 발효 사료 급여로 반추위내 caproate 생성비율이 증 가하는데 이는 알코올 발효사료 중의 알코올의 작용에 의한 것으로 사료된다.

\section{3. 건물분해율}

Fig. 8 및 9는 비지박 및 맥주박 알코올 발 효사료의 반추위내 건물소실율을 나타내고 있다. 


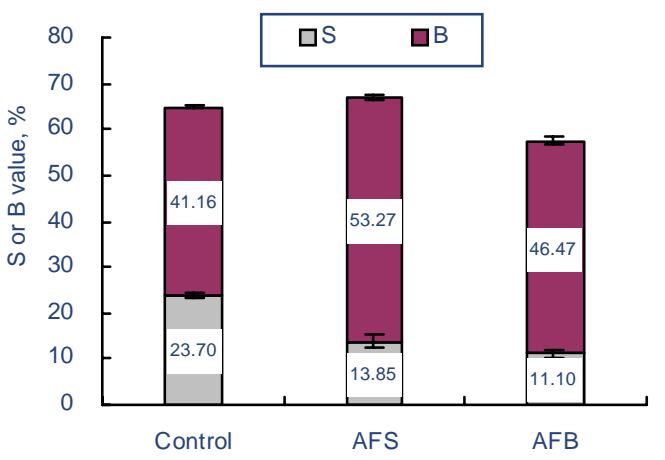

Fig. 8. Truly soluble fractions and degradable parts of alcohol-fermented soybean curd dreg (AFS) and alcohol-fermented brewery grain (AFB) during incubation in the rumen for 12 hours. $S=$ Truly soluble fractions, $B=$ Degradable parts of insoluble fraction.

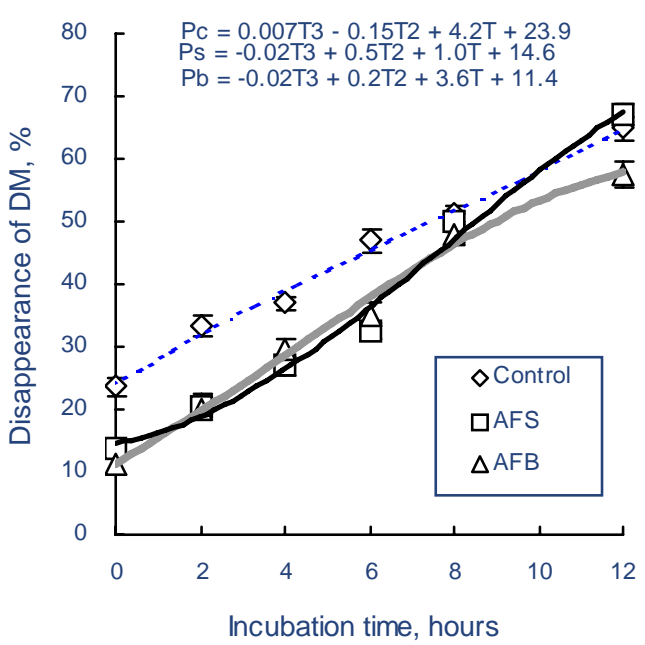

Fig. 9. Degradation rate of DM in the rumen over incubation time of alcohol-fermented soybean curd dreg (AFS) and alcohol-fermented brewery grain (AFB).

대조구, $\mathrm{AFS}$ 및 $\mathrm{AFB}$ 구의 가용성 물질 $(S)$ 함 량은 각각 23.7, 13.9 및 $11.1 \%$ 로 대조구에서 가장 높게 나타났으며, 각각의 알코올 발효사 료구들에서 낮게 나타났다 $(\mathrm{p}<0.05)$. 그러나 반 추위내에서 서서히 분해 될 수 있는 부분 $(D)$ 은
비지박 및 맥주박 알코올 발효사료가 각각 53.3 및 46.5\%로 대조구의 $41.2 \%$ 에 비해 높게 나타났다 $(\mathrm{p}<0.05)$.

반추위내 건물 분해율은 반추위내 배양 6시 간까지 대조구가 비지박 및 알코올 발효사료구 에 비해 높게 나타났으나 배양 8시간부터 12시 간사이에는 알코올 발효사료구들이 대조구에 비해 빠른 속도로 증가하는 것으로 나타났다. 따라서 반추위내 배양 12 시간에 건물 분해율이 대조구, $\mathrm{AFS}$ 및 $\mathrm{AFB}$ 구가 각각 64.9, 67.1 및 $57.6 \%$ 로 $\mathrm{AFS}$ 구가 가장 높았으며, $\mathrm{AFB}$ 구가 가 장 낮게 나타났다 $(\mathrm{p}<0.05)$. 또한 반추위내 배양 0 시간부터 12 시간 사이의 평균 건물 분해속도 는 대조구, $\mathrm{AFS}$ 및 $\mathrm{AFB}$ 구가 각각 3.4, 4.4 및 $3.9 \% \mathrm{~h}^{-1}$ 로 알코올 발효사료구들이 빠른 속도 로 분해되는 것으로 나타났다 $(\mathrm{p}<0.05)$.

이상의 실험결과에서 건물 분해율은 $\mathrm{AFB}$ 구 가 대조구보다 낮게 나타난 것은 가용성 건물 함량이 낮았기 때문으로 사료되며, 또한 알코 올 발효사료들의 가용성 물질 함량이 낮은 것 은 비지박을 이용하였기 때문에 대조구에 비해 섬유소 함량이 높고, 발효과정에 가용성 당분 이 미생물에 의해 손실되는데도 연관이 있을 것으로 판단된다. 반면에 $\mathrm{AFS}$ 구가 대조구보다 건물분해율이 낮은 것은 원료사료로 이용된 맥 주박이 가공과정중에 열처리를 받아 반추위내 에서 미생물들의 분해작용을 억제하였기 때문 으로 판단된다.

그러나 알코올 발효사료에 섬유소 함량이 높 았음에도 불구하고 배합사료에 비해 빠른 건물 분해속도를 보인 것은 알코올 발효사료 급여로 반추미생물의 섬유소 분해능력이 증가하였기 때문으로 판단된다. 이러한 결과는 엄 등(2002) 이 옥수수 알코올 발효사료를 이용하여 측정한 결과와 유사하며, 알코올에 의한 섬유소 분해 균의 감소(이, 1999)보다는 알코올 및 젖산에 의한 protozoa의 감소로 총 bacteria수가 증가하 게 되고(大柣 등, 1991) 또한 yeast의 작용으로 젖산 이용균 및 섬유소 분해균이 증가되기 때 
문으로(Dawson 등, 1990; Nisbet와 Martin, 1991) 판단된다.

본 실험의 결과를 종합하면 알코올 발효사료 는 발효과정은 알코올 뿐 만 아니라 젖산과 같 은 유기산을 생성하고 가용성 당분을 소모하는 한편 yeast와 같은 각종 발효성 미생물을 함유 하고 있으므로 반추위내 발효 pattern에 미치는 영향은 단순한 알코올 처리와 상당한 차이가 있다. 따라서 알코올 발효사료의 급여는 반추 위내 $\mathrm{pH}$ 가 저하되나 yeast균 등에 의해 반추미 생물중 젖산 이용균이 증식됨에(Nisbet와 Martin, 1991) 따라 젖산을 신속히 propionate 및 valerate 로 전환시켜 반추위벽을 통해 흡수되어 $\mathrm{pH}$ 를 상승시키는 것으로 판단된다. 한편, 알코올발효 사료 중의 젖산 등 유기산과 알코올의 일부가 직접 휘발성 지방산으로 전환되게 되므로 반추 위내에서 배양초기의 총 휘발성지방산 생성량 이 다소 증가하지만 젖산과 낮은 $\mathrm{pH}$ 에 의해 미생물의 증식이 억제되므로 반추위내 전체적 인 발효과정은 저하되는 것으로 판단된다. 또 한 알코올 발효사료 급여로 유입된 반추위내 알코올은 반추위벽을 통해 신속히 흡수 및 제 거되나 반추위내에 존재하는 동안 acetyl-CoA $\rightarrow$ caproate 대사경로를 활성화시켜 새로운 대 사성 수소[H] 제거과정을 부여하는 것으로 판 단된다. 그밖에도 알코올 발효사료 급여로 유 입되는 live yeast는 젖산 이용균 뿐 만 아니라 섬유소 분해균의 증식을 촉진하게 되므로 $\mathrm{pH}$ 저하에 의한 섬유소 분해 억제작용을 완화시키 는 것으로 판단된다.

\section{IV. 요 약}

본 실험은 비지박 및 맥주박 알코올 발효사 료 처리가 반추위내 발효특성 및 건물 분해율 에 미치는 영향을 검토하기 위하여 실시하였 다. 공시동물은 반추위 cannula가 장착된 한우 에 비지박 알코올 발효사료(AFS) 및 맥주박 알 코올 발효사료(AFB)를 급여한 후 시간별(0, 2,
4, 6, 8 및 12시간) 반추위내에서 알코올 함량, $\mathrm{pH}$ 변화, ammonia 함량, 휘발성지방산 함량 및 건물 분해율을 조사하였다. 시험구 처리는 대 조구와 비지박 (DM 20\%)과 시판중인 배합사 료(DM 87\%)를 각각 50:50의 비율로 혼합하고 당밀 $5 \%$, yeast $0.5 \%$ 를 첨가한 후 $30 \mathrm{C}$ 에서 24 시간 혐기적으로 배양한 AFS구 및 맥주박(DM $25 \%)$, 비지박(DM 20\%), 옥분 및 시판중인 배 합사료를 각각 25:25:25:25의 비율로 혼합하고 당밀 5\%, yeast 0.5 을 첨가한 후 제조한 $\mathrm{AFB}$ 로 나누어 실시하였다. 반추위내 ammonia 농도는 배양 2시간에 비지박 및 맥주박 알코올 발효사 료 처리구들이 대조구에 비해 현저히 높았으나 배양 6시간에는 비지박 및 맥주박 알코올 발효 사료급여구들이 대조구 보다 유의적으로 낮은 결과를 보였다 $(\mathrm{p}<0.05)$. 반추위내 $\mathrm{pH}$ 는 비지박 및 맥주박 알코올 발효사료처리구들이 대조구 보다 현저하게 낮게 나타났으며 $(\mathrm{p}<0.05)$, 배양 시간이 경과하면서 점차 대조구와 유사한 결과 를 보였다. 비지박 및 맥주박 알코올 발효사료 처리구들의 반추위내 알코올 농도는 반추위내 배양 4시간에 대조구에 비해 현저히 높게 나타 났으며 $(\mathrm{p}<0.05)$, 배양 6 시간에는 대조구와 알코 올 발효사료 처리구간에 유사한 결과를 보였 다. 반추위내 총휘발성지방산 함량은 반추위내 배양초기(2시간)에 비지박 및 맥주박 알코올 발 효사료처리구와 대조구간에 유사한 경향을 보 였으나 배양시간이 경과함에 따라 비지박 및 맥주박 알코올 발효사료처리구들이 대조구보다 유의적으로 감소하는 결과로 나타났다 $(\mathrm{p}<0.05)$ 비지박 및 맥주박 알코올 발효사료 처리구의 가용성건물 함량은 $(S)$ 대조구에 비해 낮은 결과 를 보였으나 $(\mathrm{p}<0.05)$, 반추위내 분해성 부분은 (D) 비지박 및 맥주박 알코올 발효사료 처리구 가 대조구에 비해 유의적으로 높은 결과를 보 였다 $(\mathrm{p}<0.05)$. 이상의 결과로 볼때 산업부산물인 비지박과 맥주박을 이용하여 알코올 발효사료 를 제조하면 가축의 생산성을 향상시킬 수 있 는 사료자원의 가능성이 있음을 알 수 있었다. 
$\mathrm{V}$.사 사

본 연구는 강원대학교 동물자원공동연구소의 실험기자재를 이용하여 실험자료를 분석하였기 에 이에 감사드립니다.

\section{VI. 인 용 문 헌}

1. 이 은. 1991. 분말알코올의 급여수준이 농후사 료 다급시 한국 재래산양의 제 1 위 내 발효 및 효소활성에 미치는 영향. 한국낙농학회지. 21(3): 201-206.

2. SAS. 1999. SAS/STAT Software for PC. Release 6.11, SAS Institute, Cary, NC, U.S.A.

3. 신종서, 박병기, 김병완. 2005. Aspergillus Oryzae 및 Saccharomyces Cerevisiae를 첨가하여 제조한 맥주박 위주 발효사료의 발효 특성 및 영양학적 특성. 한국초지학회지. 25(4):297-306.

4. 신종서, 박병기. 2006. Alcohol 사료가 in vitro 반 추위내 $\mathrm{pH}$, Ammonia, Alcohol 및 Volatile Fatty Acids 농도에 미치는 영향. 한국동물자원과학회 지. 48(1):91-100.

5. 엄창국, 박병기, 박재인, 김창혁, 고용균, 김종복, 홍병주, 신종서. 2002. 알코올 발효사료 급여가 반추위내 발효성상 및 미생물 단백질 합성에 미 치는 영향. 강원대학교 동물자원연구. 13:207219.

6. 임광철, 라창식, 신종서. 2001. 알코올발효사료의 발효특성 및 영양소 변화특성에 관한 연구. 강원 대학교 농촌개발연구. 5:169-182.

7. 임광철, 라창식, 고용균, 오진석, 홍병주, 신종서. 1999. 비지박 및 맥주박 알코올 발효사료의 in vitro 발효특성. 강원대학교 동물자원연구. 10 : 157-166.

8. 大梘和夫, 小林 剛, 松本光人, 板橋久雄. 1991. 濃厚飼料多給牛のルーメンに及ぼすエタノール 添加の影譥。畜産試驗場趼究報 第51卷. pp:9-13.

9. Armentano, L.E., T.A. Herrington, C.E., Polan, A.J. Moe, J.H. Herbein and P.U. mstadt. 1986. Ruminal degradation of dried brewers grains, wet brewers grains and soybean meal. J. Dairy Sci. 69:2124-2133.
10. AOAC. 1990. Official method of analysis(15th Ed.). Association of official analytical chemists, Washington, DC.

11. Andree Durix, C., H. Jean-Blain, P. Sallmann. and J.P. Jouany. 1991. Use of a semicontinuous culture system(RUSSITEC) to study the metabolism of ethanol in the rumen and its effects on ruminal digestion. Can. J. Anim. Sci. 71:115-123.

12. Burning, C.L. and M.T. Yokoyama. 1988. Characteristics of live and killed Brewer's yeast slurries and intoxication by intraruminal administration to cattle. J. Anim. Sci. 66:585-591.

13. Dawson, K.A., K.E. Newman and J.A. Boling. 1990. Effects of microbial supplements containing yeast and lactobacilli on roughage-fed ruminal microbial activities, J. Anim. Sci. 68: 3392-3398.

14. Dhanoa, M.A., J. France, S. Lopez, J. Dijkstra, S. J. Lister, D. R. Davies and A. Bannink. 1999. Correcting the calculation of extent of degradation to account for particulate matter loss at zero time when applying the polyester bag method. J. Anim. Sci. 77:3385-3391.

15. Mackenzie, D.D.S. 1967. Production and utilization of lactic acid by the ruminant. A review J. Dairy Sci. 50:1772-1786.

16. Moloney, A.P. and P.O. Kiely. 1999. Rumen and blood variables in steers fed grass silage or whole-crop fodder beet silage. Animal Feed Science and Technology. 81:221-235.

17. Nisbet, D.J. and S.A. Martin. 1991. Effect of a Saccharomyces cerevisiae culture on lactate utilization by the ruminal bacterium selenomonas ruminantium. J. Anim. Sci. 69:4628-4633.

18. Williams, V.J. and D.D.S. Mackenzie. 1965. The absorption of lactic acid from the reticulo-rumen of the sheep. Aust. J. Biol. Sci. 18:917-934.

19. Yoon, I.K. and M.D. Stern. 1996. Effects of Saccharomyces cerevisiae and Aspergillus oryzae in ruminal fermentation in dairy cows. J. Dairy Sci. 79:411.

(접수일자 : 2008. 1. 30 / 채택일자 : 2008. 3. 10) 